\title{
GMR
}

\section{Genetic variability of Myzus persicae nicotianae densovirus based on partial NS and VP gene sequences}

X.R. Song ${ }^{1}$ S.H. Tang ${ }^{1}$ Z. Q. Tang ${ }^{2}$ X.M. Yang ${ }^{3}$, X.W. Wang ${ }^{1}$ X.F. Wang P.J. Xu ${ }^{1}$ and G.W. Ren ${ }^{1}$

${ }^{1}$ Tobacco Research Institute, Chinese Academy of Agricultural Sciences, Qingdao, China

${ }^{2}$ Shanghai Tobacco Co., Ltd, Shanghai, China

${ }^{3}$ State Key Laboratory for Biology of Plant Diseases and Insect Pests, Institute of Plant Protection, Chinese Academy of Agricultural Sciences, Beijing, China

Corresponding authors: P.J. Xu / G.W. Ren

E-mail: xupengjun@163.com / renguangwei@caas.cn

Genet. Mol. Res. 15 (4): gmr15049099

Received August 29, 2016

Accepted October 7, 2016

Published November 21, 2016

DOI http://dx.doi.org/10.4238/gmr15049099

Copyright (C) 2016 The Authors. This is an open-access article distributed under the terms of the Creative Commons Attribution ShareAlike (CC BY-SA) 4.0 License.

ABSTRACT. We previously described a novel densovirus [Myzus
persicae nicotianae densovirus (MpnDV)] infecting M. persicae
nicotianae (Hemiptera: Aphididae) with $34 \%$ prevalence. This single-
stranded DNA virus has a 5480 -nucleotide ambisense genome and
belongs to the Densovirinae subfamily within the family Parvoviridae.
In the present study, we estimated the genetic diversity of MpnDV
using partial nonstructural protein (NS) and capsid protein (VP) gene
sequences from 10 locations in China. First, we identified MpnDV-
positive samples by amplifying a 445 -bp fragment with primers
MpDVF/MpDVR. Subsequently, we amplified and sequenced COI

Genetics and Molecular Research 15 (4): gmr15049099 
genes with primers MpCOIF/ MpCOIR, and partial NS and VP sequences with primers MpnDVF1/MpnDVR1. The respective 655-, 1461-, and 423-bp COI, NS, and VP fragments were used to analyze the genetic diversity of MpnDV using MEGA 6.0 and DnaSP 5.0. The high level of identity shared by all COI sequences ( $>99 \%)$ suggested that the aphids sampled were of the same species, and indicated population homogeneity across the 10 locations investigated. The nucleotide diversity of MpnDV sequences $(0.0020 \pm 0.0025)$ was significantly higher than that of the COI genes $(0.0002 \pm 0.0005)$. The pairwise fixation index for MpnDV was 0.832 , and the total gene flow was 0.05 . Phylogenetic analysis revealed that the MpnDV haplotypes clustered according to geographical location, except for those from the Liaoning and Shanxi provinces. In conclusion, MpnDV demonstrated a low level of gene flow and high genetic diversity, suggesting that it is vertically transmitted, and implying that endosymbiotic viruses could be used as markers in studies of insect population genetics.

Key words: Myzus persicae nicotianae; COI; MpnDV; Genetic diversity

\section{INTRODUCTION}

Densoviruses (DVs) are a group of small (18-26 nm in diameter), non-enveloped, icosahedral viruses, belonging to the subfamily Densovirinae within the family Parvoviridae (Berns et al., 1995). DVs possess a linear, single-stranded DNA genome of approximately 4-6 kb in length and can cause a "cellular dense nucleosis" pathology in their hosts. First isolated from Galleria mellonella (Meynadier et al., 1964), DVs are found in many arthropods, including the species of six insect orders (Lepidoptera, Diptera, Orthoptera, Dictyoptera, Odonata, and Hemiptera) and decapod crustaceans like shrimps and crabs (Fédière, 2000; Ryabov et al., 2009). According to their genomic structure and sequence homology, DVs are divided into five distinct genera: Ambidensovirus, Brevidensovirus, Iteradensovirus, Hepandensovirus, and Penstyldensovirus (Cotmore et al., 2014). Generally, DVs are pathogenic to their hosts (Fédière, 2000; Mutuel et al., 2010); however, some are beneficial, including Helicoverpa armigera densovirus (HaDV2) and Dysaphis plantaginea densovirus (DplDV) (Ryabov et al., 2009, Xu et al., 2012, 2014).

A globally distributed pest, the green peach aphid Myzus persicae (Hemiptera: Aphididae) feeds on more than 400 plant species belonging to 40 families, and can damage its host directly by feeding, or by transmitting plant viruses (Blackman and Eastop, 1984). Adaptation of herbivorous insects to their host plant may be the first step in speciation. The tobacco aphid M. persicae nicotianae is a subspecies of the green peach aphid adapted to feed on tobacco (Bass et al., 2013). Recently, we described a novel DV isolated from M. persicae nicotianae named M. persicae nicotianae densovirus (MpnDV), belonging to the genus Ambidensovirus within the subfamily Densovirinae, and possessing a genome comprising 5480 nucleotides. Its infection rate in wild aphid populations was found to be greater than $34 \%$ (Tang et al., 2016).

In the present study, we focused on the genetic diversity of MpnDV, estimated using partial nonstructural protein (NS) and capsid protein (VP) gene sequences in samples from

Genetics and Molecular Research 15 (4): gmr15049099 
10 locations in China. Our aims were to i) describe MpnDV genetic variation and gene flow in China, and ii) assess the possibility of utilizing an endosymbiotic virus as a marker for population genetics analysis.

\section{MATERIAL AND METHODS}

\section{Aphid samples}

Based on previous research (Tang et al., 2016), we chose 103 individual aphids infected with MpnDV from 10 locations across the following seven provinces, which have a high MpnDV infection rate: Yunnan, Henan, Guizhou, Guangdong, Liaoning, Shanxi, and Shandong (Table 1). All M. persicae were collected from tobacco plants and stored in $75 \%$ ethanol at $-20^{\circ} \mathrm{C}$.

Table 1. Details of sampling and Myzus persicae nicotianae densovirus infection rate of $M$. persicae nicotianae populations in China.

\begin{tabular}{l|c|c|c|c|c|c}
\hline Sampling site & Abbreviation & $\begin{array}{c}\text { Geographical } \\
\text { coordinates }\end{array}$ & $\begin{array}{c}\text { Collection date } \\
\text { (month/year) }\end{array}$ & $\begin{array}{c}\text { Number of } \\
\text { positive samples }\end{array}$ & $\begin{array}{c}\text { Number of } \\
\text { negative samples }\end{array}$ & $\begin{array}{c}\text { Infection } \\
\text { rate }(\%)\end{array}$ \\
\hline Qujing, Yunnan & YQ & $103^{\circ} 80^{\prime} \mathrm{E} 25^{\circ} 49^{\prime} \mathrm{N}$ & $7 / 2011$ & 10 & 2 & 83.33 \\
\hline Xuchang, Henan & $\mathrm{HX}$ & $113^{\circ} 85^{\prime} \mathrm{E} 34^{\circ} 04^{\prime} \mathrm{N}$ & $11 / 2015$ & 10 & 2 & 83.33 \\
\hline Zhunyi, Guizhou & $\mathrm{GZ}$ & $106^{\circ} 93^{\prime} \mathrm{E} 27^{\circ} 73^{\prime} \mathrm{N}$ & $8 / 2011$ & 12 & 1 & 92.31 \\
\hline Nanxiong, Guangdong & $\mathrm{GN}$ & $121^{\circ} 45^{\prime} \mathrm{E} 42^{\circ} 04^{\prime} \mathrm{N}$ & $11 / 2015$ & 10 & 1 & 83.33 \\
\hline Fumeng, Liaoning & $\mathrm{LF}$ & $116^{\circ} 32^{\prime} \mathrm{E} 33^{\circ} 18^{\prime} \mathrm{N}$ & $7 / 2011$ & 10 & 0 & 100.00 \\
\hline Rizhao, Shandong & $\mathrm{SR}$ & $119^{\circ} 53^{\prime} \mathrm{E} 35^{\circ} 42^{\prime} \mathrm{N}$ & $7 / 2011$ & 10 & 11 & 100.00 \\
\hline Chuxiong, Yunnan & $\mathrm{YC}$ & $101^{\circ} 31^{\prime} \mathrm{E} 25^{\circ} 02^{\prime} \mathrm{N}$ & $7 / 2011$ & 11.67 \\
\hline Nanniwan, Shanxi & $\mathrm{SN}$ & $101^{\circ} 60^{\prime} \mathrm{E} 36^{\circ} 60^{\prime} \mathrm{N}$ & $7 / 2011$ & 10 & 2 & 83.33 \\
\hline Yishui, Shandong & $\mathrm{SY}$ & $118^{\circ} 37^{\prime} \mathrm{E} 35^{\circ} 47^{\prime} \mathrm{N}$ & $7 / 2011$ & 10 & 1 & 90.91 \\
\hline Laiwu, Shandong & $\mathrm{SL}$ & $117^{\circ} 68^{\prime} \mathrm{E} 36^{\circ} 21^{\prime} \mathrm{N}$ & $7 / 2011$ & 10 & & 5 \\
\hline
\end{tabular}

\section{DNA extraction and polymerase chain reaction (PCR) amplification}

Genomic DNA was extracted with a TIANamp Genomic DNA Kit (Tiangen, Beijing, China) following the manufacturer protocol. MpnDV-infected samples were identified by PCR with primers MpDVF/MpDVR (Tang et al., 2016). A fragment of the cytochrome c oxidase subunit I (COI) gene was then amplified from the selected samples with primers MpCOIF (5'-TATTCGTCCAGGGATTGC-3')/MpCOIR (5'-TATGGAATATAATTTCTTCAATTGG-3'), as were partial MpnDV NS and VP gene sequences using primers MpnDVF (5'-GTTCATCGCCCAGGAATGTC-3')/MpnDVR (5'-AAAGACATGGTTGCTGGCTG-3'). For COI genes, the PCR program consisted of 4 min at $94^{\circ} \mathrm{C}$, then $30 \mathrm{~s}$ at $94^{\circ} \mathrm{C}$ repeated for 35 cycles, $30 \mathrm{~s}$ at $54^{\circ} \mathrm{C}$, and $30 \mathrm{~s}$ at $72^{\circ} \mathrm{C}$, followed by $10 \mathrm{~min}$ at $72^{\circ} \mathrm{C}$. For MpnDV genes, it comprised $4 \mathrm{~min}$ at $94^{\circ} \mathrm{C}$, then $30 \mathrm{~s}$ at $94^{\circ} \mathrm{C}$ repeated for 35 cycles, $30 \mathrm{~s}$ at $54^{\circ} \mathrm{C}$, and $2 \mathrm{~min}$ at $72^{\circ} \mathrm{C}$, followed by $10 \mathrm{~min}$ at $72^{\circ} \mathrm{C}$.

\section{Sequence analysis}

Alignment of nucleotide sequences was performed using the CLUSTAL W software (Thompson et al., 1994). For the partial NS and VP nucleotide sequences, a neighbor-joining (NJ) tree based on haplotypes was constructed using the Kimura two-parameter distance model, Poisson-corrected distances, and 1000 bootstrap replicates in MEGA 6.0 (Tamura et 
al., 2013). The DnaSP 5.0 software was used to analyze haplotype (gene) diversity $(H d)$, nucleotide diversity $(P i)$, the average number of nucleotide differences $(K)$, mutations across the whole sequence and Tajima's $D$ as a test of neutral evolution (Librado and Rozas, 2009). Analysis of molecular variance (AMOVA) was performed with Arlequin 3.5 to test the hierarchical genetic structure of populations, with significance being determined based on 10,000 permutations (Excoffier and Lischer, 2010).

\section{RESULTS}

\section{Sequence variation}

Approximately 10 samples from each location (a total of 103 individuals; Table 1) were used for amplification and sequencing, including COI fragments of $655 \mathrm{bp}$; and partial MpnDV NS and VP fragments amounting to 1896 bp (NS fragments: $1461 \mathrm{bp}$; VP fragments: $423 \mathrm{bp}$ ). The COI genes shared more than $99 \%$ identity and contained seven variable sites $(1.07 \%$ of the amplified fragment length), suggesting a high level of similarity between samples from different locations.

The base composition of the amplified MpnDV fragments was as follows: $\mathrm{T}=20.93 \%$; $=29.89 \% ; \mathrm{A}=32.44 \%$; and $\mathrm{G}=16.76 \%$. In total, 119 variable sites were detected in the $\mathrm{MpnDV}$ genes, including 94 parsimony-informative and 25 singleton sites, accounting for approximately $6.28 \%$ of the amplified fragment length. In total, 17 transversions ( $7 \mathrm{~T}$ to A, $6 \mathrm{~A}$ to $\mathrm{T}, 3 \mathrm{G}$ to $\mathrm{C}, 1$ $\mathrm{C}$ to $\mathrm{G}$ ) and 102 transitions were detected in the MpnDV fragments, with two sites showing both transitions and transversions. The transversion/transition ratio $(\mathrm{R})$ was 0.167 .

\section{Genetic diversity}

The number of haplotypes, and $H d, P i$, and $K$ within each population tested are shown in Tables 2 and 3. Six haplotypes were detected for the COI gene, of which only one was present in every population, the other five being exclusive to the population at a particular site. Genetic differentiation was evident at only three locations. $H d$ values were between 0.200 and 0.644 , whereas $P i$ and $K$ values ranged from 0.0003 to 0.0017 and 0.200 to 1.156, respectively. The average nucleotide diversity of COI sequences was $0.0002 \pm 0.0005$. In addition, 39 haplotypes were identified from the partial MpnDV gene sequences across the 10 locations. Samples from Chuxiong (Yunnan Province) exhibited only one haplotype, while multiple haplotypes were observed at all other sites. $H d$ varied from 0.345 to 0.956 , while $P i$ and $K$ ranged from 0.0006 to 0.0077 and 0.727 to 14.511 , respectively. The average nucleotide diversity of MpnDV sequences was $0.0020 \pm 0.0025$.

\section{Tests of neutrality and estimations of population expansion}

Tajima's $D$ was implemented using DnaSP 5.0. For the COI genes, this metric ranged from -1.3882 to -1.1117 across populations, and did not significantly differ $(\mathrm{P}>0.10$; Table 2). Values of Tajima's $D$ for the partial MpnDV NS and VP genes varied between -1.9245 and 0.6032 (Table 3). Qujing (Yunnan Province; YQ) and Xuchang (Henan Province; HX) significantly differed in this regard from other populations $(\mathrm{P}<0.05)$, for which Tajima's $D$ was consistent with a neutral model of evolution $(\mathrm{P}>0.05)$.

Genetics and Molecular Research 15 (4): gmr15049099 
Table 2. Haplotype distribution, genetic diversity, and assessment of neutral evolution for different geographic populations of Myzus persicae nicotianae, based on the COI gene.

\begin{tabular}{l|c|c|c|c|c|c}
\hline Population code & $\begin{array}{c}\text { Number of } \\
\text { haplotypes }\end{array}$ & $\begin{array}{c}\text { Haplotype } \\
\text { diversity }(H d)\end{array}$ & $\begin{array}{c}\text { Nucleotide } \\
\text { diversity }(P i)\end{array}$ & $\begin{array}{c}\text { Average number of } \\
\text { nucleotide differences }(K)\end{array}$ & Tajima's $D$ & Statistical significance \\
\hline YQ & 1 & 0 & 0 & - & - & - \\
\hline HX & 1 & 0 & 0 & - & - & - \\
\hline GZ & 1 & 0 & 0 & - & - & - \\
\hline GN & 2 & 0.200 & 0.0003 & 0.200 & -1.1117 & P $>0.10$ \\
\hline LF & 1 & 0 & 0 & - & - & - \\
\hline SR & 2 & 0.200 & 0.0003 & 0.200 & - & -1.1117 \\
\hline YC & 1 & 0 & 0 & - & -1.3882 & - \\
\hline SN & 4 & 0.644 & 0.0017 & -156 & - & P $>0.10$ \\
\hline SY & 1 & 0 & 0 & - & - & - \\
\hline
\end{tabular}

Table 3. Haplotype distribution, genetic diversity, and assessment of neutral evolution for different geographic populations of Myzus persicae nicotianae densovirus based on partial NS and VP gene sequences.

\begin{tabular}{l|c|c|c|c|c|c}
\hline Population code & $\begin{array}{c}\text { Number of } \\
\text { haplotypes }\end{array}$ & $\begin{array}{c}\text { Haplotype } \\
\text { diversity }(\mathrm{Hd})\end{array}$ & $\begin{array}{c}\text { Nucleotide } \\
\text { diversity }(\mathrm{P})\end{array}$ & $\begin{array}{c}\text { Average number of } \\
\text { nucleotide differences }(K)\end{array}$ & Tajima's $D$ & Statistical significance \\
\hline YQ & 2 & 0.378 & 0.0007 & 1.400 & -1.8391 & $\mathrm{P}<0.05$ \\
\hline HX & 7 & 0.867 & 0.0011 & 2.000 & -1.9245 & $\mathrm{P}<0.05$ \\
\hline GZ & 4 & 0.691 & 0 & 0.836 & -0.6278 & $\mathrm{P}>0.10$ \\
\hline GN & 3 & 0.491 & 0 & 0.727 & -1.7116 & $0.10>\mathrm{P}>0.05$ \\
\hline LF & 3 & 0.473 & 0.0022 & 4.109 & -0.3247 & $\mathrm{P}>0.10$ \\
\hline SR & 2 & 0.600 & 0.0028 & 5.333 & 0.3558 & $\mathrm{P}>0.10$ \\
\hline YC & 1 & 0 & 0 & - & - & - \\
\hline SN & 8 & 0.956 & 0.0077 & 14.511 & 0.0061 & $\mathrm{P}>0.10$ \\
\hline SY & 3 & 0.345 & 0.0006 & 1.164 & -0.5416 & $\mathrm{P}>0.10$ \\
\hline SL & 6 & 0.891 & 0.0049 & 9.273 & 0.6032 & $\mathrm{P}>0.10$ \\
\hline
\end{tabular}

\section{Gene flow and genetic differentiation analysis}

Concerning the COI genes, the pairwise fixation index $\left(F_{\mathrm{ST}}\right)$ between populations ranged from -0.004 to 0.019 , with a total $F_{\mathrm{ST}}$ of 0.026 and a total gene flow $\left(N_{m}\right)$ of 8.75 (Table 4). For the MpnDV genes considered in this study, the $F_{\mathrm{ST}}$ values for all population pairs were greater than $0.25(0.317-0.987)$, suggesting a high degree of differentiation between populations. The total $F_{\mathrm{ST}}$ for the MpnDV genes was 0.832 and the total $N_{m}$ was 0.05 (Table 4). The high degree of MpnDV genetic differentiation among the locations examined was also confirmed by AMOVA (Table 5).

Table 4. Pairwise fixation index $\left(F_{\mathrm{ST}}\right)$ between 10 populations (values for COI sequences are shown under the diagonal, those for Myzus persicae nicotianae densovirus sequences are above the diagonal).

\begin{tabular}{l|c|c|c|c|c|c|c|c|c|c}
\hline Population code & YQ & HX & GZ & GN & LF & SR & YC & SN & SY & SL \\
\hline YQ & & 0.943 & 0.962 & 0.964 & 0.897 & 0.840 & 0.925 & 0.974 & 0.950 & 0.785 \\
\hline HX & 0 & & 0.945 & 0.943 & 0.851 & 0.820 & 0.881 & 0.957 & 0.920 & 0.707 \\
\hline GZ & 0 & 0 & & 0.976 & 0.923 & 0.888 & 0.951 & 0.982 & 0.968 & 0.838 \\
\hline GN & 0 & 0 & 0.019 & & 0.891 & 0.832 & 0.917 & 0.987 & 0.936 & 0.714 \\
\hline LF & 0 & 0 & 0 & 0 & & 0.679 & 0.778 & 0.911 & 0.779 & 0.520 \\
\hline SR & 0 & 0 & 0.019 & 0 & 0 & & 0.559 & 0.880 & 0.701 & 0.317 \\
\hline YC & 0 & 0 & 0.010 & 0 & 0 & -0.004 & & 0.956 & 0.857 & 0.452 \\
\hline SN & 0 & 0 & 0 & 0 & 0 & 0.010 & 0.010 & & 0.976 & 0.808 \\
\hline SY & 0 & 0 & 0.019 & 0 & 0 & 0 & 0 & 0.010 & & 0.420 \\
\hline SL & 0 & 0 & 0 & 0 & 0 & 0 & 0 & 0 & 0 & \\
\hline
\end{tabular}

Genetics and Molecular Research 15 (4): gmr15049099 


\section{Table 5. Analysis of molecular variation based on NS/VP and COI gene sequences.}

\begin{tabular}{l|l|c|c|c}
\hline \multirow{2}{*}{ Marker } & Source of variation & d.f. & Variation (\%) & Fixation index $\left(F_{\mathrm{ST}}\right)$ \\
\cline { 2 - 4 } & Among populations & 9 & 83.17 & $0.832(\mathrm{P}<0.001)$ \\
\cline { 2 - 4 } & Within populations & 93 & 64.80 & \\
\cline { 2 - 4 } COI & Among populations & 9 & 2.58 & $0.026(\mathrm{P}=0.015)$ \\
\cline { 2 - 4 } & Within populations & 93 & 97.42 & \\
\hline
\end{tabular}

d.f. $=$ degrees of freedom.

\section{Phylogenetic analysis}

The phylogenetic tree of haplotype sequences revealed that samples from the same province clustered together, with the exception of those from Liaoning and Shanxi (Figure 1).

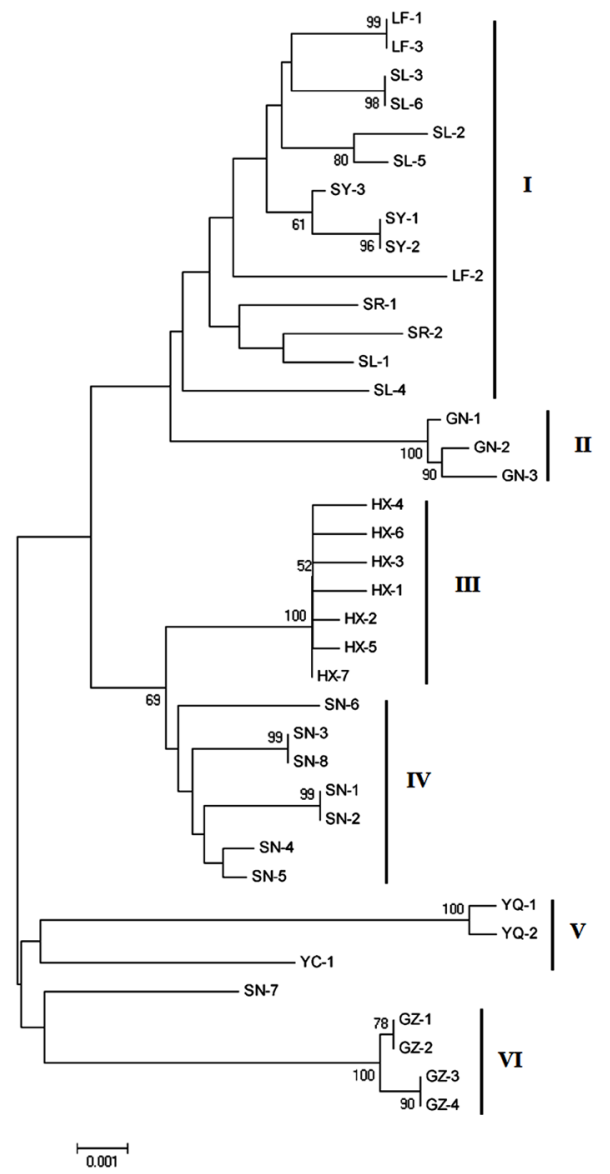

Figure 1. Neighbor-joining phylogenetic tree based on the Kimura two-parameter distance model using haplotype nucleotide sequences of Myzus persicae nicotianae densovirus from different locations. Letters represent locations (Table 1) and numbers signify haplotypes within each location. Roman numerals denote provinces from which samples were collected, as follows: I = Shandong, except for LF (Liaoning); II = Guangdong; III = Henan; IV = Shanxi; V = Yunnan; VI = Guizhou, except for SN (Shanxi). Bootstrap values (1000 pseudoreplicates) $>50 \%$ are indicated on the nodes. The scale bar represents 0.001 substitutions per site.

Genetics and Molecular Research 15 (4): gmr15049099 


\section{DISCUSSION}

During recent decades, more than $30 \mathrm{DVs}$ have been reported in species of Arthropoda (Cotmore et al., 2014). However, few studies have focused on the genetic diversity of geographically separated populations of these viruses. Previously, we discovered a novel DV (MpnDV) in M. persicae nicotianae, infecting 34\% of individuals in wild aphid populations (Tang et al., 2016). In the present study, we revealed that this virus exhibits a high level of genetic diversity across populations, by sampling from 10 locations in China.

DNA barcoding based on COI sequences, for which intraspecific variation in identity is typically lower than $2 \%$, has been widely used for species identification (Hebert and Gregory, 2005; Evans and Paulay, 2012; Taylor and Harris, 2012). However, because of such high identity values between members of the same species, it is difficult to analyze genetic diversity among different populations using COI sequences. In the present study, we detected little variation in the COI sequences, which were associated with low $H d$ and $P i$ values within each population. These results suggest that there were no significant differences between samples from different locations, and that the aphids used in this study were of the same species. Interestingly, 119 variable sites were identified in the partial NS and VP genes of MpnDV, and the number of transitions was much higher than that of transversions. In general, M. persicae nicotianae demonstrates very high haplotype diversity, implying that this organism adapts to local environmental changes. The $H d, P i$, and $K$ values of the MpnDV sequences were higher than those calculated for the COI genes, suggesting a higher level of diversity across different locations. Tajima's $D(-0.6672)$ indicated that the neutral evolution model applies to the MpnDV population, and that it has not undergone a recent bottleneck (Tajima, 1989; Nohara et al., 2010; Wang and $\mathrm{Xu}, 2014)$. The values of this test for each of the $10 \mathrm{MpnDV}$ populations sampled did not significantly differ, with the exception of the YQ and HX sites $(\mathrm{P}<0.05)$. This suggests a recent population expansion in these locations, resulting in the formation of different MpnDV genetic groups (Harpending et al., 1998).

$F_{\mathrm{ST}}$ is used to analyze variation in gene frequencies among populations (Flint-Garcia et al., 2003). In our study, the $F_{\mathrm{ST}}(0.832)$ and $N_{m}(0.05)$ values calculated for MpnDV suggested low $N_{m}$ and high genetic differentiation within and among locations (Allendorf, 1983; Wright, 1984). Consistent with this, AMOVA revealed genetic variation both within and between populations. Using microsatellites, we previously demonstrated that $M$. persicae in China are highly genetically diverse; however, they were found to form only two distinct clusters (Zhao et al., 2015a). Moreover, haplotypes among different Schlechtendalia chinensis populations do not cluster by location ( $\mathrm{Li}$ and Ren, 2009). Here, phylogenetic analysis revealed that MpnDV haplotypes clustered according to geographical origin, except for those found in Liaoning and Shanxi provinces, likely due to long-distance migration of $M$. persicae nicotianae (Loxdale et al., 1993). Aphids from Liaoning may have crossed the Bohai Sea, subsequently interacting with other populations, while others might have migrated from Shanxi to Yunnan (Gao et al., 2016). From the distribution of haplotypes in the NJ tree and their locations, no significant relationship between haplotype and geographical distance was evident. Most genetic variation was among populations, implying that physical isolation is not the dominant factor responsible for the genetic differentiation observed. There was no significant correlation between genetic distance and geographical distance or altitude, in accordance with our previous findings (Zhao et al., 2015a). Our results suggest that MpnDV sequences show greater variation and higher resolving power than COI sequences; therefore, endosymbiotic viruses might be considered

Genetics and Molecular Research 15 (4): gmr15049099 
as potential markers for analysis of insect populations, assuming a sufficiently high infection rate. DVs can be transmitted to their hosts both vertically and horizontally (Xu et al., 2014), and aphids are capable of long-distance migration, resulting in a high rate of $N_{m}$ and decreased genetic diversity (Llewellyn et al., 2003; Zhang et al., 2014; Zhao et al., 2015b). However, our results indicate that MpnDV is highly diverse genetically, suggesting that this virus is, in general, vertically transmitted.

The number of samples used in this study was relatively small, and the geographical region considered was narrow. Therefore, our results are not entirely representative of all populations and the full extent of variation in genetic structure. Future studies should include more samples from a greater number of locations.

\section{CONCLUSION}

In this study, we focused on the genetic diversity of MpnDV. Using samples from 10 different locations in China, we revealed that this virus of $M$. persicae nicotianae exhibits a high level of genetic diversity. Phylogenetic analysis indicated that MpnDV haplotype nucleotide sequences cluster according to geographically defined populations, except for samples from Liaoning and Shanxi provinces, possibly due to long-distance migration of their tobacco aphid hosts. Thus, MpnDV demonstrates low levels of $N_{m}$ and high genetic diversity, implying vertical transmission. Taken together, these results suggest that endosymbiotic viruses should be considered as potential markers for the analysis of geographical insect populations.

\section{Conflicts of interest}

The authors declare no conflict of interest.

\section{ACKNOWLEDGMENTS}

Research supported by Shanghai Tobacco Co., Ltd (\#SZBCW2015-00876), the Science Foundation for Young Scholars of Institute of Tobacco Research of CAAS (\#2015B03) and the Agricultural Science and Technology Innovation Program (\#ASTIP-TRIC04).

\section{REFERENCES}

Allendorf FW (1983). Isolation, gene flow and genetic differentiation among populations. In: Genetics and conservation (Schonewald-Cox CM, Chambers SM, MacBryde B and Thomas L, eds.). Benjamin-Cummings, London, 51-65.

Bass C, Zimmer CT, Riveron JM, Wilding CS, et al. (2013). Gene amplification and microsatellite polymorphism underlie a recent insect host shift. Proc. Natl. Acad. Sci. USA 110: 19460-19465.http://dx.doi.org/10.1073/pnas.1314122110

Berns KI, Bergoin M, Bloom M, Lederman M, et al. (1995). The family Parvoviridae. In: Virus taxonomy: classification and nomenclature of viruses. Sixth report of the International Committee on Taxonomy of Viruses (Murphy FA, Fauquet CM, Bishop DHL, Ghabrial SA, et al., eds.). Springer-Verlag, Vienna, 169-178.

Blackman RL and Eastop VF (1984). Aphids on the world's crops: an identification and information guide. John Wiley $\&$ Sons, Hoboken.

Cotmore SF, Agbandje-McKenna M, Chiorini JA, Mukha DV, et al. (2014). The family Parvoviridae. Arch. Virol. 159: 1239-1247.http://dx.doi.org/10.1007/s00705-013-1914-1

Evans N and Paulay G (2012). DNA barcoding methods for invertebrates. Methods Mol. Biol. 858: 47-77. http://dx.doi. org/10.1007/978-1-61779-591-6_4

Excoffier L and Lischer HE (2010). Arlequin suite ver 3.5: a new series of programs to perform population genetics analyses under Linux and Windows. Mol. Ecol. Resour. 10: 564-567.http://dx.doi.org/10.1111/j.1755-0998.2010.02847.x

Genetics and Molecular Research 15 (4): gmr15049099 
Fédière G (2000). Epidemiology and pathology of Densovirinae. Contrib. Microbiol. 4: 1-11. http://dx.doi. org $/ 10.1159 / 000060332$

Flint-Garcia SA, Thornsberry JM and Buckler ES, 4th (2003). Structure of linkage disequilibrium in plants. Annu. Rev. Plant Biol. 54: 357-374.http://dx.doi.org/10.1146/annurev.arplant.54.031902.134907

Gao F, Jin J, Zou W, Liao F, et al. (2016). Geographically driven adaptation of chilli veinal mottle virus revealed by genetic diversity analysis of the coat protein gene. Arch. Virol. 161: 1329-1333. http://dx.doi.org/10.1007/s00705016-2761-7

Harpending HC, Batzer MA, Gurven M, Jorde LB, et al. (1998). Genetic traces of ancient demography. Proc. Natl. Acad. Sci. USA 95: 1961-1967.http://dx.doi.org/10.1073/pnas.95.4.1961

Hebert PD and Gregory TR (2005). The promise of DNA barcoding for taxonomy. Syst. Biol. 54: 852-859. http://dx.doi. org $/ 10.1080 / 10635150500354886$

Li JB and Ren ZM (2009). Genetic diversity among Schlechtendalia chinensis individuals revealed by Cyt b sequences. J. Fudan Univ. Nat. Sci. 48: 680-686.

Librado P and Rozas J (2009). DnaSP v5: a software for comprehensive analysis of DNA polymorphism data. Bioinformatics 25: 1451-1452.http://dx.doi.org/10.1093/bioinformatics/btp187

Llewellyn KS, Loxdale HD, Harrington R, Brookes CP, et al. (2003). Migration and genetic structure of the grain aphid (Sitobion avenae) in Britain related to climate and clonal fluctuation as revealed using microsatellites. Mol. Ecol. 12: 21-34. http://dx.doi.org/10.1046/j.1365-294X.2003.01703.x

Loxdale HD, Hardie J, Halbert S, Foottit R, et al. (1993). The relative importance of short- and long-range movement of flying aphids. Biol. Rev. Camb. Philos. Soc. 68: 291-311. http://dx.doi.org/10.1111/j.1469-185X.1993.tb00998.x

Meynadier G, Vago C, Plantevin G and Atger P (1964). Virose d'un type inhabituel chez le lépidoptère Galleria mellonella L. Revue de Zool. Agric. et Appliquée 63: 207-208.

Mutuel D, Ravallec M, Chabi B, Multeau C, et al. (2010). Pathogenesis of Junonia coenia densovirus in Spodoptera frugiperda: a route of infection that leads to hypoxia. Virology 403: 137-144. http://dx.doi.org/10.1016/j. virol.2010.04.003

Nohara K, Takeuchi H, Tsuzaki T, Suzuki N, et al. (2010). Genetic variability and stock structure of red tilefish Branchiostegus japonicus inferred from mtDNA sequence analysis. Fish. Sci. 76: 75-81. http://dx.doi.org/10.1007/ s12562-009-0188-8

Ryabov EV, Keane G, Naish N, Evered C, et al. (2009). Densovirus induces winged morphs in asexual clones of the rosy apple aphid, Dysaphis plantaginea. Proc. Natl. Acad. Sci. USA 106: 8465-8470. http://dx.doi.org/10.1073/ pnas.0901389106

Tajima F (1989). Statistical method for testing the neutral mutation hypothesis by DNA polymorphism. Genetics 123: 585-595.

Tamura K, Stecher G, Peterson D, Filipski A, et al. (2013). MEGA6: molecular evolutionary genetics analysis version 6.0. Mol. Biol. Evol. 30: 2725-2729. http://dx.doi.org/10.1093/molbev/mst197

Tang S, Song X, Xue L, Wang X, et al. (2016). Characterization and distribution analysis of a densovirus infecting Myzus persicae nicotianae (Hemiptera: Aphididae). J. Econ. Entomol. 109: 580-587. http://dx.doi.org/10.1093/jee/tov399

Taylor HR and Harris WE (2012). An emergent science on the brink of irrelevance: a review of the past 8 years of DNA barcoding. Mol. Ecol. Resour. 12: 377-388. http://dx.doi.org/10.1111/j.1755-0998.2012.03119.x

Thompson JD, Higgins DG and Gibson TJ (1994). CLUSTAL W: improving the sensitivity of progressive multiple sequence alignment through sequence weighting, position-specific gap penalties and weight matrix choice. Nucleic Acids Res. 22: 4673-4680.http://dx.doi.org/10.1093/nar/22.22.4673

Wang XY and Xu GQ (2014). Genetic differentiation and gene flow among geographic populations of Spodoptera exigua (Lepidoptera: Noctuidae) in China. Acta Entomol. Sin. 57: 1061-1074.

Wright S (1984). Evolution and the genetics of populations, volume 3: experimental results and evolutionary deductions. University of Chicago Press, Chicago.

Xu P, Cheng P, Liu Z, Li Y, et al. (2012). Complete genome sequence of a monosense densovirus infecting the cotton bollworm, Helicoverpa armigera. J. Virol. 86: 10909. http://dx.doi.org/10.1128/JVI.01912-12

Xu P, Liu Y, Graham RI, Wilson K, et al. (2014). Densovirus is a mutualistic symbiont of a global crop pest (Helicoverpa armigera) and protects against a baculovirus and Bt biopesticide. PLoS Pathog. 10: e1004490. http://dx.doi. org/10.1371/journal.ppat.1004490

Zhang B, Ma C, Edwards O, Fuller S, et al. (2014). The mitochondrial genome of the Russian wheat aphid Diuraphis noxia: large repetitive sequences between $\operatorname{trnE}$ and $\operatorname{trnF}$ in aphids. Gene 533: 253-260. http://dx.doi.org/10.1016/j. gene.2013.09.064

Zhao C, Yang XM, Tang SH, Xu PJ, et al. (2015a). Population genetic structure of Myzus persicae nicotianae (Hemiptera: Aphididae) in China by microsatellite analysis. Genet. Mol. Res. 14: 17159-17169. http://dx.doi.org/10.4238/2015. December.16.16

Zhao CL, Chen H, Song J and Cui BK (2015b). Phylogeny and taxonomy of the genus Abundisporus (Polyporales, Basidiomycota). Mycol. Prog. 14: 38. http://dx.doi.org/10.1007/s11557-015-1062-y

Genetics and Molecular Research 15 (4): gmr15049099 